\title{
The Nationalisation of the Yugoslav Economy
}

The change in the ownership structure of the Yugoslav economy started in the late '80s. In the beginning it developed in two directions: privatization of "social enterprises" and rapid increase in the number of privately owned firms. However, political processes dramatically changed the conditions of property transformation at the beginning of '90s. Dissolution of the state, civil war and UN sanctions have drastically deteriorated economic conditions, while the keeping of the power by the old ruling group has frozen political initiative for the transformation and brought unfavorable changes in the legal system. Increase in the number of privately owned firms continued, but these firms are as a rule small in terms of capital and number of employees, and oriented at trade - which is often highly profitable, as they operate at the margin or outside the legal system. At the same time the ruling group completed the nationalisation of some sectors of the economy, brought under indirect control the majority of the remaining biggest industrial firms and banks, and practically annulled the fairly advanced process of privatization in the former "social enterprises". In this way the groups command over the majority of the economy is retained. Briefly speaking, two most important features of the previous socialist system - political and economic control over the society - are maintained by the old ruling elite in the Federal Republic of Yugoslavia (Serbia and Montenegro) so far.

Structure of Yugoslav (Serbia and Montenegro) economy:

$\begin{array}{lllll}\text { capital in \% } & 1991 & 1992 & 1993 & 1994 \\ \text { social capital } & 88,8 & 79,4 & 43,5 & 81,9 \\ \text { shares } & 6,1 & 13,4 & 16,9 & 12,5 \\ \text { investments } & 3,5 & 3,9 & 3,6 & 3,4 \\ \text { private capital } & 1,6 & 3,3 & 36,0 & 2,2 \\ \text { total } & 100 & 100 & 100 & 100\end{array}$

But competitive elites in both sub-systems have been gradually developing, their institutionalized existence being the indicator of a gradual systemic change.

The contradictory development in the process of transformation of Yugoslav society is well illustrated by the Property Transformation Revaluation Act (1994). It was the first and last proposal of one opposition party ever accepted by the Serbian Parliament under the rule of the Socialist party of Serbia. It was proposed by the Democratic party out of demagogic reasons, but in the era when the population rightly treated then ongoing privatization process as robbery. Namely, in the period between February, 1993 - February 1994 inflation in the FR Yugoslavia exploded to 116 trillion percents, but even before it was high reaching hundreds of percents. This enormously decreased the real 
value of shares. Namely, according to the Law, revaluation of unsold shares was practiced only once in a year. The real reason why the ruling elite in Serbia backed the idea of revaluation was not social justice but its own interest: to keep - through nationalisation of the property - the full control over big enterprises and to resume the clientelism from the previous communist period. Nationalisation gave the Serbian government an opportunity to appoint not only the executive board members but also the director and indirectly the enterprise managerial staff. Membership in several boards gives power but also a very high honorarium. Membership in managerial stuff for persons close to the ruling elite automatically gives an access to executive boards of other public and state owned firms.

But, with the lifting of the UN sanctions a moment of truth is knocking at the door. Even if Serbian economy is devastated by the sanctions, the real causes of entropy are rooted in the previous period of socialist self-management and the so called "contracted economy" introduced in '80s. According to official statistical data, in comparison to 1989, industrial production in 1993 was 25\% , and per capita GNP only 40\% (910 US dollars). Industrial production in the first half of 1994 was only 35\% in comparison to 1989 . Approximately the same percentage has been reached in 1995. Internal debt of state banks to the Yugoslav population is 4 billion US dollars. The foreign debt is approximately 9 billion dollars. The unemployment rate is at $25-30 \%$ plus 800,000 people who were on "forced vacation" due to UN sanctions (40\% of the labor force). At the same time, all structural reasons which caused the crisis of the Yugoslav society and economy are permanently on agenda as unsolved issues.

Laslo Sekelj / Mladen Lazic, Institut za evropske studije Beograd 